\title{
No Need to Reinvent the Wheel: Promoting Donations of Private Company Shares and Real Estate
}

by

Adam Aptowitzer

- There is significant opportunity to unlock new types of financing for Canada's charitable sector. This can be done by extending favourable tax treatment to the donation of private company shares and real estate. Amid controversy over its proposed small business tax reforms, Ottawa could implement these changes to increase the tax planning options for owners of private company shares and real estate.

- Past proposals to enact such favourable treatment created an entirely new mechanism to address concerns regarding proper valuation and other mischief. These proposals, however, created unintended consequences and were overly complex.

- This E-Brief recommends using the current system for the donation of private company shares, as well as extending it to donations of real estate and simply amending the tax rate applicable to such transactions. As in the case with donations of publicly traded shares, the capital gain would be excluded from income.

For several years, voices in the charity community have been advocating for change to the regime by which private company shares and non-environmentally sensitive land may be donated to charity. ${ }^{1}$ The argument for making the change has been that, conceptually, there should be no difference, for purposes of tax treatment on gifting, between the donation of shares of publicly

The author thanks Rosalie Wyonch, Kevin Milligan, members of the Fiscal and Tax Competitiveness Council, and several anonymous reviewers for comments on an earlier draft. The author retains responsibility for any errors and the views expressed.

1 In this E-Brief, the terms "real estate" or "land" used alone without any reference to environmental property, refer to land that, for purposes of donation, has not been deemed environmentally sensitive. 
traded securities and privately held ones. ${ }^{2}$ This conceptual argument broke down somewhat in the discussion of real estate because of the good and obvious reasons to prioritize keeping sensitive lands in the hands of environmental charities over having the property sold and the proceeds donated to charity. Aside from such property, there is merit to the argument that the donation of all real estate or its sale price should be treated equally.

In 2015, the federal government included a vague promise of change to effectively equalize the tax treatment of donations of both private securities with public securities, and regular real estate with environmental property (hereafter the proposals) (Government of Canada 2015). In so doing, the government created a mechanism to shelter some amount of capital gain from the sale of private company shares and real estate. The amount of the sheltered gain was to be proportionate to the total amount of the proceeds of the sale, which were then donated to a registered charity. The technical wording of these initiatives was released after Parliament rose before the 2015 election and, following the election in the fall, the proposals were quietly dropped.

For many years the government of Canada has been considering the tax implications of the donations of private company shares and has developed a regime designed to deal with problems of valuation and the control of private companies by charities. The proposals developed an entirely new mechanism to deal with both these potential problems. Rather than introduce a new and complicated regime, however, I recommend that the government revisit the current system, which avoids major mischief by donors and charities.

The donation of real estate requires deep consideration because any system that gives a tax credit for such donations will undermine the gifting of that same property to charities dedicated to its preservation. The extent of the damage rises along with the amount of the tax credit. The government could leverage the existing mechanisms for the donation of private company shares while ensuring that the incentive to donate environmental property for preservation is always greater than the donation of real estate in general. This E-Brief suggests recommendations to unlock the store of wealth in private shares and real estate as an avenue for charity financing by reforming the tax treatment of these kinds of property.

\section{Current Programs}

Before discussing the addition of new provisions for the donation of private company shares and real estate, it is useful to give some background information on the current programs. Any new incentives must work harmoniously with those already in place to minimize avoidance and ensure the integrity of the income tax system. Without doubt, any appetite for change to the Income Tax Act represents issues and opportunities for potential reforms.

Taxes are owed when an owner disposes of an asset that has increased in value. This disposition includes donations of assets. However, when property is donated to charity, the donor receives a donation tax credit that offsets either all or some of the taxes owing depending on the nature of the item donated. Indeed, certain incentives create donation tax credits in excess of the taxes owing on the disposition and can be used to offset taxes owing from other sources in the year of donation or in future years.

\section{Gifts of Environmentally Sensitive Real Estate}

Since 1995, the Act has contained an incentive for the donation of environmental property to an environmental

2 Donations of publicly traded securities are not subject to capital gains tax but receive a tax receipt for the full fair market value. 
charity (the Ecogifts program). Specifically, if the property is certified as ecological property by the minister of the environment, and the owner donates it to an acceptable environmental charity, the receipted amount is determined by the minister and there is no capital gains tax on the disposition of the property. ${ }^{3}$ In these circumstances, the total amount of the receipt is available to offset taxes from other sources. Moreover, in recent years the Act was amended to allow for a 10-year carry forward for the tax credits generated on the donation.

By requiring the minister to determine the value of the receipt, there is no risk of an inflated receipt being issued. While this system has proven workable, a similar process for the donation of non-environmental real estate would be unworkable owing to the sheer volume of such property.

\section{Gifts of Non-Qualifying Securities}

The Act already contains provisions for the donation of private company shares (non-qualifying securities, or NQS). Predictably, the Act is concerned with various types of mischief that may result from the donation of such securities, and a number of anti-avoidance mechanisms have been put in place. When the shares are donated to a charity that is at arm's length from the donor, the value can be determined by appraisal, but when the donation is to a non-arm's-length foundation, the value of the receipt is not determined until the shares are sold by the charity within five years (if they are not sold within five years, no receipt is issued). ${ }^{4}$

Parts of these rules were developed to address concerns about control. If the donation is made to an arm'slength charity, control over the shares would automatically shift, and a receipt can be issued right away. If the donation is to a non-arm's-length private foundation, a receipt cannot be issued until control has changed hands (or one of the other allowable scenarios occurs).

Under the current system, the donor must pay tax on 50 percent of the capital gain associated with private company shares, even if the whole amount or the securities themselves are donated. In contrast, the capital gains on publicly traded securities are not subject to tax when the securities are donated.

\section{The Proposals}

In an attempt to further unlock the store of wealth in real estate and private company shares as an avenue of financing for Canadian charities, the 2015 federal budget announced the government's intention "to give effect to the Proposals relating to Donations Involving Private Corporation Shares or Real Estate described in the budget documents tabled by the Minister of Finance in the House of Commons on Budget Day" (Government of Canada 2015, p. 496).

Interestingly, Budget 2015 did not include the typical legal wording that would give effect to the proposals. The technical wording, released by the Department of Finance in July 2015, made it clear that there would be a reduction in the taxable capital gain proportional to the sale price donated to charity. In other words, the only way to ensure that the entire amount is not taxable is to donate the entire sale amount to charity (see Box 1 for further explanation). The proposed incentive program was accompanied by a number of restrictions:

3 If the land were inventory rather than capital, tax would still be payable under this program.

4 The shares are also eligible for a receipt during the five-year period if they cease to be non-qualifying - if, for example, they become publicly traded. 
- the donation must take place within 30 days after the disposition of the property;

- the taxpayer must be resident in Canada;

- the property must be Canadian;

- the sale must be to an arm's-length buyer;

- added to these restrictions are anti-avoidance provisions that reverse the proposed sheltering in the event of self-dealing; ${ }^{5}$ and

- the amount of the tax receipt has to be proportionate to the amount of the sale price donated to charity (see Box 1).

\section{Box 1}

If a donor's cost for shares is $\$ 500,000$ and she sells them for $\$ 2,500,000$, there would, under normal circumstances, be a $\$ 2,000,000$ capital gain. If the donor donates $\$ 1,000,000$ (40 percent) of that sale price to charity, the actual amount that would be exempt from tax would be $\$ 800,000$ (40 percent of the capital gain). Half of the rest of the capital gain $(\$ 1,200,000)$ would be exempt owing to the 50 percent inclusion rate.

So the taxable capital gain would be $\$ 600,000$, with taxes owing based on the appropriate combined federal/provincial tax rate.

The donor also has a tax credit that more than offsets the tax payable from the sale. In the example above, the donor would have a tax receipt for $\$ 1,000,000$ and a taxable capital gain of $\$ 600,000$, meaning that $\$ 400,000$ of the receipt is remaining to offset tax from other sources. If the entire sale price were donated to charity, the entire tax credit would be available to offset tax from other sources because the entire capital gain would be exempt from taxation.

The proposals differed from the current system for donation of NQS in a number of ways. Most important, by sheltering a proportionate amount of the capital gain from taxation in addition to a donation tax receipt, the incentive to donate is higher in the proposals than under the current system. The proposals introduced a completely new mechanism that attempts to use the market for valuation and encourages an immediate disposition of the asset being donated. This differs from the current system, which delays valuation and the issuing of a tax receipt until the shares are sold to a third party and NQS are donated to a non-arm'slength private foundation (and, in certain circumstances, an arm's-length public foundation). The proposals represented an entirely different mechanism for valuation and disposition of assets for donation to any recipient, even if the ostensible problem was only with private foundations.

5 Where the anti-avoidance rules apply, the exemption will be reversed by including the previously exempted amount in the income of the donor in the year of the reacquisition by the donor (or the non-arm's-length person) or the redemption. 


\section{Lessons from the Proposals}

The current government has articulated its intention not to proceed with the proposed tax incentives for the donation of real estate and private company shares, ostensibly because of concerns about the practical implementation of the proposals. It is important to understand the content and the policy thinking behind these concerns: they are useful in illuminating the difficulties in creating a system to provide incentives for relevant types of donations. The design of an effective system to unlock new kinds of property as avenues of financing for Canada's many charitable organizations should take account of these difficulties and address these concerns.

Many shareholders benefit from the $\$ 800,000$ lifetime capital gains exemption on the sale of shares in Qualified Small Business Corporations ( $\$ 1$ million for farm and fish corporations) - an amount that keeps rising. Tax advisers have ways of multiplying this exemption among members of a family. As sales of shares in these amounts do not attract tax, there is no additional tax incentive to donate the proceeds or the shares other than to create the donation tax credits to shield tax from other sources. Indeed, the same principle applies to donations of the proceeds from the sale of principal residences, which account for 77.7 percent of real estate value held by families in Canada (Statistics Canada 2012). ${ }^{6}$

With respect to the donation of real estate, the proposals provided the same tax treatment on the donation of the proceeds of real estate as on donated environmental property. ${ }^{7}$ The net effect was to make the donors indifferent to donating environmental property as an Ecogift or as regular real estate. Moreover, if donors were not interested in gifting the entire property, they could dispose of environmental property in the open market and simply make a donation to any charity of their choosing. The undermining of the Ecogift program would exist with any system that creates an incentive for the donation of real estate equal to the donation of environmental property. Furthermore, any system that deals with the valuation of land by encouraging its sale would undermine charities that seek the donation of specific pieces of land. For example, charities in urban areas may seek land adjacent or contiguous to their current operations. However, if donors are required to sell the property on the open market in order to achieve tax relief, there is no guarantee the charity would be able to get the land (unless the donor agrees to sell it to the charity and donate the money back).

When corporations make donations they are entitled to a deduction from their income of the value of the receipt. This provision assumes that the corporation has income from which to make the deduction. Consequently, many small business corporations, particularly those winding down and therefore most likely to consider a donation of real estate, would not benefit from the donation. Although there are complicated methods by which the corporate shareholders may be able to move the property into their own hands and make the donation, it may be wise to consider a simplified mechanism.

The Canadian income tax system allows taxpayers to deduct from their income an amount attributable to the depreciation of their capital assets, including buildings. As a simple example, a taxpayer who owns a building used for business operations could deduct 4 percent of the book value of the building each year. When the

6 Table 205-0002, Survey of Financial Security (SFS), composition of assets (including Employer Pension Plans valued on a termination basis) and debts held by all family units, by age group, Canada and provinces. http://www5.statcan. gc.ca/cansim/a26?lang=eng\&id=2050002.

7 With the singular exception that tax credits from Ecogift donations may be carried forward for 10 years. 
building is sold, the owner is taxed 100 percent on the amount deducted over the years (this "recapture" is taxed as income), and everything over that amount is taxed 50 percent as a capital gain. Because, in most provinces, the tax credits from a donation offset taxes from income, there are no leftover credits to offset taxes from other sources when the recapture amount is donated. ${ }^{8}$ Hence, under the proposals, the only tax incentive to give exists when the donor donates some of the capital gain - if there is any.

Another important requirement of the proposals was that the proceeds of disposition be donated within 30 days of the "sale." With real estate, that may be simple, but many sales of businesses are based on a longer payout - often five years. Put simply, the prospective donor would not have the cash available to take advantage of the new proposals, significantly blunting their effectiveness. ${ }^{9}$ Presumably, the policy reason behind this decision was to get the cash into the hands of the charity as quickly as possible. However, given the practical problems with such a requirement, it cannot feature as part of any newly developed system.

\section{Recommendations}

It is clear, then, that the proposals contained significant practical and philosophical problems in their design. Indeed, the system for the donation of real estate contained within it a fundamental contradiction with the Ecogifts program. Yet real estate is a rich vein of wealth, and, to serve the public interest, the government should encourage its donation. My recommendations provide only partial tax relief to the donation of real estate.

A regime to incentivize the donations of privately traded securities gives rise to a much different set of concerns than those involving the donation of real estate. We cannot expect that the same solution should be able to solve all the problems, as the proposals seemed to contemplate. However, improvements can be made to the existing system for donation of private company shares - and the ability to extend these preferences to the donation of real property - without completely cannibalizing the successful Ecogifts program.

\section{Private Company Shares}

The central element of the proposals was the donation of proceeds from the sale of the property. This formulation was made to avoid the problems inherent in the valuation of gifts in kind by a third party. However, a system to address concerns for proper valuation is already enacted in the Income Tax Act.

As discussed above, where the donation is received by an arm's-length charity, an appraisal of the value from a qualified appraiser will suffice. That is the standard approach for all gifts in kind. Charities themselves have the incentive to refuse illiquid donations so that donations of this type do not remain on their balance sheets and

8 Indeed, in many provinces the tax credits on donation are less than the tax rates applied to a dollar earned at the highest bracket. Applied to the above scenario, donors would need to donate some of the capital gain - if any - where only 50 percent is taxable, just to be in a position where they do not end up owing tax on the sale.

9 The same principle may apply to those who sell their shares in December but do not receive the full payment in that year. The result may well be a donation in the following year, but because such credits cannot be carried back, the purpose of the incentive has been completely undermined. 
become part of their spending obligations through the disbursement quota. ${ }^{10}$ Where the donation is made to a non-arm's-length organization, the value of the receipt issued would be the value that the charity receives when it disposes of the shares (within five years) or when the shares cease to be "non-qualifying" (e.g., become publicly traded). There seems to be no reason to diverge from the current system, along with its mechanism of a deferred receipt/income inclusion, for the purpose of increasing the available tax credit. If the system works under the current tax provisions, then it would continue to work in a system where no tax is payable on a valid donation. I suggest, therefore, that the government extend the current mechanism for all donations of privately traded securities and implement a simple legislative increase to exclude the entire disposition from tax - akin to the treatment of publicly traded securities and certain other assets.

The current tax credit for the donation in kind of privately traded shares already contains mechanisms to encourage the third-party valuation of shares. Specifically, in certain circumstances, no receipt is issued until the shares are purchased by a third party or they can be sold on the open market. The current regime applies the usual tax rate to these donations, but a differential rate of taxation would simply be a change to the tax on disposition, not a change to the current system by which these securities are donated and valued. I recommend that Ottawa enact special treatment of private company shares by simply excluding the capital gain from inclusion in taxable income. That is similar to the treatment of donations of publicly traded securities. If the shares are never purchased, then the donor is never entitled to a receipt. This system accomplishes the same object as the one achieved under the now abandoned proposals.

Some of the problems I have identified with the proposals will not be eliminated simply by tweaking the current system. For example, the disposition of shares of a Qualified Small Business Corporation would still not have any tax consequences, so there is no additional incentive to donating them. But they do avoid the major issue of ensuring that the donor has the necessary cash from the sale to effect the donation within 30 days. It also allows for the ongoing use of tax-planning techniques already developed to allow for the liquidation of such shares on death. The sale of the shares as part of estate planning is a major missing component from the proposals.

\section{Real Estate}

As described above, there is a fundamental problem with creating incentives for the donation of real estate because it necessarily undermines the tax benefits of donating environmental property. We have two possible solutions: first, to prevent the disposition of environmental property to any but an environmental charity clearly an unfair restriction on trade and administratively difficult to accomplish; and second, to ensure that the incentive to donate environmental property is always greater than the donation of real estate. ${ }^{11}$

Further, any system that promotes the sale of real estate as a means of determining a valuation unnecessarily weakens a charity's ability to solicit the donation of real estate that may be essential to its growth. As a model for an appropriate system, then, we can look to the regime for the donation of private company shares. As stated

10 The disbursement quota is a statutory requirement that charities, in year two, spend 3.5 percent of assets not used directly in their charitable activities in year one.

11 In some ways this solution already exists: the tax credits from the donation of environmental property are available for a 10-year carry forward as opposed to the five years available in all other cases. It is, however, a non-monetary incentive entirely dependent on the donor's circumstances. 
above, the current system allows for the receipting of NQS based on a third-party appraisal (when donated to an arm's-length public foundation or charitable organization). Charities have ample motivation to issue accurate donation receipts because the failure to do so could result in the loss of charitable status with the Canada Revenue Agency. Charities that are not arm's length from their donors would still be subject to issuing a receipt for the value of the property when sold - and only when sold. Indeed, considering that real estate is a far more liquid holding than privately traded securities, such a system could work even more effectively than that for NQS. In a circumstance where real estate is donated to a private foundation, with a possible five-year hold, the amount of recapture should be held in reserve as not taxable until a receipt is issued - if ever.

Such a regime does not imply that the rate of taxation on such donations is automatically set. These provisions are simply intended to ensure the integrity of the donation system - the rate of tax could be set at an optimal number to encourage the donation of real estate while not unduly undermining the Ecogifts program. We are not in a position to make a recommendation on this point because a great deal of econometric research remains to be done. It should suffice, though, that the donation of real estate can be encouraged without damaging our ecological heritage. ${ }^{12}$

One tangential benefit of imposing the current NQS regime on the donation of real estate is that donors would not have the option of donating only a portion of the asset - as was the case under the proposals.

\section{Conclusions}

There is significant opportunity to unlock new types of financing for the charitable sector. By increasing the types of assets that can receive favourable tax treatment, the government is increasing the choice available to Canadians who wish to donate.

Fundamentally, the proposals were, in theory, a step in the right direction, but concerns arose with respect to their implementation. For the donation of both private company shares and real estate, the government should simply modify the current system for the donation of NQS - a regime that has served us well in the past. It also has the advantage of having been tested and observed over many years.

12 The possibility exists for a super credit on the donation of ecological property: for example, where governments provide a credit not only to offset the taxes owing on donation but also to provide additional credits to offset other taxes owing. Although such a system may be effective, it would, however, open a door the Department of Finance and other levels of government want shut tightly and would likely lead to significant political disputes among the branches of government. 


\section{References}

Aptowitzer, Adam, and Benjamin Dachis. 2015. At the Crossroads: Nerw Ideas for Charity Finance in Canada. Commentary 343. Toronto: C.D. Howe Institute.

Government of Canada. 2015. "Strong Leadership: A balanced-budget, low-tax plan for jobs, growth and security.” Ottawa. April 21.

Statistics Canada. 2012. Table 205-0002, Survey of Financial Security (SFS. Accessed at: http://www5. statcan.gc.ca/cansim/a26?lang=eng\&id=2050002.

This E-Brief is a publication of the C.D. Howe Institute.

Adam Aptowitzer, L.L.B., is a tax lawyer specializing in issues related to charities at Drache Aptowitzer LLP in Ottawa. He is also Associate Professor at the University of Ottawa Law School.

This E-Brief is available at www.cdhowe.org.

Permission is granted to reprint this text if the content is not altered and proper attribution is provided. 